\title{
YES OR NO, OR HOW TO ANSWER A NEGATIVE QUESTION
}

\section{INTRODUCTION}

The aim of this paper is to investigate the status of particles in answers to negative questions. A yes-no question is a question that asks to identify whether $\mathrm{P}$ or not $\mathrm{P}$ is true (Hamblin 1973), and is minimally answered by an answering particle. Answers to yes-no questions have given rise to a large amount of literature since Pope (1972), who gives a detailed description of the types of answers across languages. She distinguishes two major systems: truth-based systems, in which the particles confirm or disconfirm the true value presupposed by the question, like in Japanese in (1), and polarity-based systems, in which particles express positive or negative polarity, like in Spanish in (2).
(1) a) Kimi tsukareteiru?
Hai. // Iie.
you tired
yes no
$(\text { Jap })^{1}$
'Are you tired?'
'Yes (I am).' // 'No (I am not).'
b) Kimi tsukareteinai?
Hai (tsukareteinai). // Iie (tsukareteiru desu).
you tired-neg
'Aren't you tired?'
yes (tired-neg) no (tired be)
'I am not'. // 'I am.'

(2) a) ¿Enviaste una carta a Paul?

Si. // No.

(Sp)

'Did you send a letter to Paul?'

'Yes.' // 'No.'

b) ¿No enviaste una carta a Paul?

No. // Si.

'Didn't you send a letter to Paul?'

'No.' // 'Yes, I did.'

The same particles are used to answer both positive and negative questions, although some languages "reinforce" the positive particle to negative questions, e.g. the conjunction but before yes in Czech, see (3), and some languages use a specific particle for positive answers to negative questions, e.g. si instead of oui in French, see (4).

(3) a) Poslaljsi Pavlovi dopis? sent be.2sg to-Paul letter 'Did you sent Paul a letter?'

b) Neposlal jsi Pavlovi dopis? neg-sent be.2sg to-Paul letter 'Didn't you send Paul a letter?'
Ano. // Ne.
$(=2 \mathrm{a})$
$(\mathrm{Cz})$
yes no
Ne. $\quad / /$ Ale ano. $\quad(=2 \mathrm{~b}) \quad(\mathrm{Cz})$
no but yes

* hana.gruet-skrabalova@univ-bpclermont.fr

1 This example is from my Japanese informant. 
(4) a) Est-il venu?

is-he come

'Has he come?'

b) N' est-il pas venu?

neg-did-he not come

'Hasn't he come?'
Oui. // Non.

yes no

Non. // *ui. / Si.

no yes yes

Although the behaviour of particles has been described for many languages (see Laka 1990; Martins 1994; Holmberg 2001; Holmberg 2012; Farkas 2010; Krifka 2012 a.o.), it has been hardly observed that particles could be used in both ways within a same language. So, Holmberg $(2001 ; 2013)$ notes that negative questions with not in English can be confirmed by both yes and no, see (5), because not is ambiguous between sentential and VP-negation. In other words, he argues that yes only confirms negative questions when not is interpreted as VP-negation, thus when the question is rather affirmative that truly negative.

(5) a) Is John not coming? No, he is not. (sentential Neg) / Yes, he is not. (VP-Neg)

b) Isn't John coming? No, he isn't. (sentential Neg) / *Yes, he isn't. (*VP-Neg)

This paper shows that negative questions in Czech can be both confirmed and disconfirmed by yes or no, see (6), which makes the particles potentially ambiguous. The negation is expressed by the negative prefix on the finite verb, cf. (3) above.

(6) Rodiče nejsou doma? parents neg-are home 'Aren't the parents at home?'
Ne. / Ano. // Ne. / Ale ano.

no yes no but yes

'They are not.' // 'They are.'

The use of the particles is however not free. It is argued that it depends on the interpretation of the sentential negation in the question, which can be either true or expletive (cf. Brown and Franks 1995 for Russian negative questions). This semantic distinction is furthermore tightly linked to the syntactic position of the negation, according to which we can distinguish between negative interrogative clauses and negative declarative clauses used as questions (cf. Gunlogson 2001). An analysis in terms of absolute and relative polarity (Farkas 2010) is then proposed to account for the mixed behaviour of answering particles: particles express absolute polarity in answers to interrogative questions, whose polarity is open (Holmberg 2001), and relative polarity in answers to declarative questions, whose polarity has been already specified.

The paper is structured as follows. Section 2 describes two types of answers to negative questions in Czech, showing a mixed behaviour of answering particles. Section 3 deals with negative questions; several pieces of evidence are discussed in order to show that we have to distinguish between questions with expletive negation and questions with true negation and that this distinction accounts for the distribution of answering particles. Section 4 focuses on expression of the polarity in the answers; it is 
proposed that particles express absolute or relative polarity depending on the polarity of the question. Section 5 sums up the paper.

\section{TWO TYPES OF ANSWERS TO NEGATIVE QUESTIONS}

To show that both answering particles in Czech can confirm and disconfirm a negative question, we need to specify that Czech (like many other languages, e.g. Basque, Finish, Portuguese, Irish) can reply a question by using the finite verb of the question, either alone or in combination with a particle, see (7). The positive verb always indicates a positive answer and the negative verb a negative answer. Verbal answers will therefore be used throughout the paper to clearly state the polarity of the answer.
(7) a) Poslal jsi Pavlovi dopis? sent be.2sg to-Paul letter 'Did you send Paul a letter?'
(Ano) poslal. // (Ne) neposlal. yes sent no neg.sent neg-sent be.2sg to-Paul letter no neg.sent but yes sent 'Didn't you send Paul a letter?'
b) Neposlal jsi Pavlovi dopis? (Ne) neposlal. // (Ale ano) poslal.

Let us look again at the negative question in (6), repeated in (8) and completed by verbal answers (in brackets) that can accompany the particles:

(8) Rodiče nejsou doma? parents neg-are home

'Aren't the parents at home?'
A: Ne (nejsou). // Ale ano (jsou). no neg-are but yes are
B: Ano (nejsou). // Ne (jsou). yes neg-are no are 'They are not.' // 'They are.'

The puzzle we are dealing here is that the question 'Aren't the parents at home?' can be answered in two ways, which I call type A and type B answers and which are summarized in table 1 below. In type A answers, ne means 'they are not', while ano means 'they are'. In contrast, in type B answers, ne means 'they are', while ano means 'they are not'. The particles appear, thus, to be ambiguous; they may also combine with both negative and positive verb. The interpretation of each answer is however clearly given by the verb, meaning that the combination of the particle and the verb cannot be considered as redundant. ${ }^{2}$

2 Speakers actually often prefer verbal answers to answering particles alone. 
Table 1: Two types of answers to negative questions

\begin{tabular}{|l|c|c|}
\cline { 2 - 3 } \multicolumn{1}{c|}{} & Negative answers & Positive answers \\
\hline Type A answers & ne + neg-V & (ale) ano + verb \\
\hline Type B answers & ano + neg-V & ne + V \\
\hline
\end{tabular}

Example (8) seems to indicate that A and B answers are always equally available, but this is not true. First, in oral production, the particles in B answers are better emphasized and separated from the verb, which confirms that they bear another information than the verb (i.e. they do not indicate the absolute polarity of the answer, see section 4):
(9) Jan nemluvi
francouzsky?
?Ne, mluví.
// NE - mluví.
John neg-speaks French
'John doesn't speak French?'
no he-speaks NO he-speaks

Furthermore, B answers are generally judged inacceptable as replies to questions containing an initial verb, meaning that the question's form matters for the choice of the answer (see section 3 for more details):
(10) Neposlaljsi mu ten dopis? *Ano (neposlal). / Neposlal. //*Ne (poslal). / Poslal. neg-sent be.2sg to-him the letter yes (neg-sent) neg-sent no (sent) sent 'Didn't you send him the letter?'

Importantly, however, B answers can be used as replies to negative questions with negative polarity items like ani (not-one/not-any), see (11). Since any must be licensed by sentential negation (see section 3.3 for more on NPIs), negative questions confirmed by $\mathrm{B}$ answers must contain sentential negation. They, therefore, differ from negative questions with not in English that allow confirmation by yes only with VP-negation reading, see (5) above.

(11) Jan*(ne)pozval ani jednoho spolužáka? Ano (ani jednoho).// Ne (nějakého pozval).
John (neg-)invited no one schoolmate yes no one no (he) some invited 'Didn’t John invite any of his schoolmates?'

The difference between A and B answers cannot thus be due to the contrast between sentential and VP-negation, but it must nevertheless be linked to the negation. The hypothesis I explore in the following section is that in some negative questions, negation loses its negative force and behaves likes expletive negation. Negative questions with expletive negation behave like positive questions, whose polarity I assume to be open (following Holmberg 2001). Thus, they are answered by type A answers, in which particles indicate absolute (positive or negative) polarity. In contrast, negative questions 
with true negation behave like negative assertions, whose polarity is fixed. Thus, they are answered by type B answers, in which particles indicate relative polarity, i.e. (dis) agreement with the polarity of the question.

\section{NEGATIVE QUESTIONS}

The main claim of this section is that in some questions, negation is not true (from the truth conditional point of view), but expletive. The term 'expletive' (or 'pleonastic') negation usually refers to a phonologically overt negative morpheme that lacks negative semantic content (see Espinal 1992 for Romance; Brown \& Franks 1995 for Slavic). It typically appears after lexical items like before or until, and in constructions with verbs like to fear or to doubt, see (12). Contrary to true negation, expletive negation cannot license NI-phrases in Slavic, compare (13a) and (13b). ${ }^{3}$ For Brown \& Franks (1995: 262), "canonical pleonastic negation (in Slavic) consists of a NegP with either an empty or vacuous specifier position. The head position is filled with $n e$ [...], but there is no Negation Operator, the bearer of the semantics, to give the sentence negative force".
a) Il n'est pas arrivé. he neg-is not arrived
'He hasn't arrived.'
(ne....pas: true $\mathrm{Neg})^{4}$
b) Il faut finir avant qu'il n'arrive. it must finish before that-he neg-arrives
'We have to finish before he arrives.'
c) Je suis sûr que nous ne sommes pas en retard. (ne: true Neg)
I am sure that we neg are not late
'I'm sure that we are not late.'
d) Je crains que nous ne soyons en retard. (ne: expletive Neg)
I fear that we neg are late
'I am afraid that we are late.'

(13) a) Nikdo nepřišel.

$$
\text { (ne-: true Neg) }
$$

nobody neg-come

'Nobody came.'

b) Bojím se, aby někdo / *nikdo nepř̌šel pozdě. (ne-: expletive Neg) I-fear refl. that somebody / nobody neg-come late

'I am afraid that somebody might come late.'

More interestingly, Brown \& Franks (1995) and Abels (2002) observe that negative questions with the interrogative particle $l i$ in Russian do not license NI-phrases,

3 See section 3.4 for licensing of NPIs in Czech.

4 In (12a) and (12c), ne can be omitted. 
which would suggest that they also contain expletive negation. However, the same questions license Genitive of Negation. Moreover, questions without particle $l i$ license both NI-phrases and Genitive of Negation. To account for this asymmetry, Brown \& Franks (1995: 266) claim that "certain independently motivated grammatical principles, such as Rizzi's (1990) Relativized Minimality, conspire to prevent negation from having negative force [...] in Russian Yes/No questions". In their analysis, negation in li-questions is forced to be pleonastic, because a Yes/No operator in Spec-CP prevents $n e$ to be licensed by the Negation Operator (adjoined to $\mathrm{CP}$ ) when ne (cliticized on V) moves to C. I pursue here the view that negation can be rendered expletive by the interrogation. In other words, the interrogative operator blocks the negative operator to bind $n e$ when $\mathrm{Verb}(\mathrm{Neg})$-moves to $\mathrm{C}$, so that $n e$ cannot retain its negative force. I will show that despite the absence of Genitive of Negation in Czech, the phenomenon of expletive negation is relevant and allows to account for the distribution of A and B answers to negative questions.

\subsection{Word Order}

Main questions in Czech do not contain an overt interrogative C. Still, assuming that syntactic clause-type (declarative, interrogative, exclamative) and illucutionary act (assertion, questioning, exclamation) can be dissociated (Beyssade \& Marandin 2006), we can distinguish two types of questions. Czech is a SVO language in which interrogative clauses are formed by V-fronting (and $w h$-fronting in case of $w h$-questions), see (14). Interrogative clauses are typically used as questions. But declarative clauses with (not only) SVO order can also be used to express questioning. In the following discussion, I will show that negative interrogatives and negative declarative clauses used as questions differ with respect to negative presupposition, combinability with evidential and modal adverbials, licensing of NPIs, and also the answers they receive.

(14) a) Marie dala dětem koláčky./*Dala Marie dětemkoláčky. (declarative) Mary.nom given children.dat cakes.acc /given Mary.nom children.dat cakes.acc 'Mary gave children some cakes.'

b) Dala Marie dètem koláčky? / Komu dala Mariekoláčky? (interrogative) given Mary.nom children.dat cakes.acc/who.dat given Mary.nom cakes.acc 'Did Mary give children some cakes?' / 'To whom did Mary give some cakes?'

\subsection{Negative Presupposition}

Negative interrogatives (with non-focal intonation ${ }^{5}$ ) are used to elicit information, to solicit an opinion, or to make a polite request for action (see Gunlogson 2001 for detailed distribution). They do not convey any presupposition. Questions in (15) are understood as open questions that the speaker uses to find out whether the doctor is or is not in his office, and whether the addressee did or did not take a wrong road. They can only be answered by type A answers.

5 See ex. (21) for focal intonation. 
a) Není doktor $v$ ordinaci? Ne, není. / *Ano, není. // Ano, je. / *Ne, je. neg-is doctor in office no neg-is yes is yes is no is 'Isn't the doctor in his office?' 'He is not.' // 'He is.'

b) Q: Kam jdete? Nespletli jste si náhodou cestu? where go.2pl neg-mistaken be.2pl refl. accidentally road 'Where are you going? Didn't you accidentally take the wrong road?' A: Ne, nespletli. /*Ano, nespletli. // Ano, spletli. /*Ne, spletli. no neg-mistaken yes neg-mistaken yes mistaken no mistaken 'We didn't.' // 'We did.'

On the contrary, negative declarative questions are typically used when the speaker expects a negative answer or when (s)he wishes to express an emotional response (surprise, disagreement, etc.). They convey a negative presupposition like negative declarative clauses. Questions in (16) are typically used when the speaker expects the doctor not to be in his office or if he is surprised that the addressee did not find the right way. Type B answers are then used to confirm or disconfirm this negative bias.

a) Doktornení vordinaci? Ano, neni. // Ne, je. doctor neg-is in office yes neg-is no is 'The doctor isn't in his office?' 'He isn't.' // 'He is.'

b) Jak je to možné? Vy jste nenašli správnou cestu? Ano, nenašli. // Ne, našli. how is it possible you be.2pl neg-found right way yes neg-found no found 'How is it possible? You didn't find the right way? 'We didn't.' // 'We did.'

However, the biased interpretation in (16) is not obligatory, which explains that these questions can be also answered by type A answers, as shown in (16') (see section 3.4 , ex. (24) for the analysis). The ambiguity of declarative questions can be avoided by using final rising intonation for neutral interpretation (like in interrogative clauses) and rising intonation followed by final fall for biased interpretation.
a) Doktor neni $v$ ordinaci? doctor neg-is in office
Ne, není. I/ Ale ano, je. 'The doctor isn't in his office?' no neg-is but yes is
'He isn't.' // 'He is.'

\subsection{Evidential and Modal Adverbs}

The fact that only negative declarative questions can express a negative bias is confirmed by their compatibility with adverbs expressing modality or evidentiality, like určitě ('of course'), žrejmé ('apparently'), jistě ('surely'), see (17). These adverbs are considered as bias markers and cannot appear in interrogative clauses in English either, see (18) (cf. Huddleston 1994). 
(17) a) Pavels tím určitě nesouhlasil? / \#Nesouhlasils tím Pavel určitě?? Paul with that certainly neg-agreed / neg-agreed with that Paul certainly 'Paul did certainly not agree with that?'

b) Prosefoři ještě žrejmě neodešli? / \#Neodešli ještě profesoři ž̌ejmě? professors yet apparently neg-left / neg-left yet professors apparently 'Apparently, the professors haven't yet left?

c) Vy nejste pravděpodobnězdejši? /\#Nejste pravděpodobnězdejší? you neg-are probably from-here/ you-neg-are probably from-here 'You are probably not from here?'

(18) a) \#Did they certainly agree with that?

b) \#Have they apparently left?

c) \#Are you probably from here?

\subsection{Negative Polarity Items (NPIs)}

Three types of negative polarity items can be distinguished in Czech: NI-phrases (nikdo 'nobody', nic 'nothing', žádný N, 'no N', etc.), weak NPIs (vủbec 'at all', sebemenši 'the slightest') and strict NPIs (ani jeden 'no one'), see Dočekal (2016). NI-phrases are only licensed by clausemate negation, i.e. they must be in the scope of sentential negation, see (19a). Weak NPIs are licensed in the context of some downward entailing operator (yes-no questions, conditionals, constituent negation etc., see Gajewski 2011). The strict NPI ani jeden is grammatical in contexts with local or superordinate negation, see (19b) and (19c), and in contexts with the preposition bez 'without'. ${ }^{6}$

a) Nikdo nepotkal/*potkalv lese medvěda. nobody neg-met / met in forest bear 'Nobody met a bear in the forest.'

b) Anijeden z nich se $v$ lese neztratil/ztratil. no one of them refl. in forest neg-lost / lost 'Not one of them got lost in the forest.'

c) Nechce, aby se ani jeden ztratil v lese. he-neg-wants that refl. no one lost in forest 'He doesn't want anyone to get lost in the forest.'

If we look at NI-phrases in questions, we can observe that negative declarative questions license NI-phrases as subject exactly like negative declarative clauses, while negative interrogatives do not, see (20). Moreover, negative interrogatives in (20a) can only be answered by type A answers, while B answers are possible in (20b). The

6 It is also sensitive to truth conditions and to the pragmatic part of meaning, which explains that it is not acceptable in all downward entailing contexts (Dočekal 2016). 
two contrasts are explained if interrogative clauses contain expletive negation and declarative clauses true negation, cf. (13) above. ${ }^{7}$

a) Nepotkal *nikdo/ někdo v lese medvěda? Ne / *Ano, nepotkal. neg-met nobody/somebody in forest bear no yes neg-met (he did not) 'Did anybody meet a bear in the forest?' Ale ano / *Ne, potkal. but yes no met (he did)

b) Nikdo /někdo nepotkal vlese medvěda? Ano (nikdo)./Ne (někdo ho potkal). nobody / somebody neg-met in forest bear yes (nobody) no (somebody did) 'Nobody met/Somebody didn't meet a bear in the forest?'

The contrast observed above needs to be specified in more detail. First, NI-phrases are ungrammatical in interrogative clauses in (20a) and (21a) below, but they are acceptable in (21b), where they are used with focal interpretation. Brown \& Franks (1995) argue however that negation cannot be expletive with focal interrogation because the verb doesn't raise to $C$ (recall that expletive negation in questions is triggered in contexts with Verb(Neg)-raising to C). I claim that the verb in (21b) actually doesn't rise to $\mathrm{C}$ but stays in $\mathrm{T}$, whose specifier is occupied by a null expletive subject (because of the EPP feature). The focused subject stays in Spec-vP. The fact that an overt expletive subject ( $v$ )on ('he') can co-occur with the focused subject in (21c) makes this claim plausible.

a) Nepotřbuje *nikdo / někdo pomoct? neg-needs nobody / somebody help

'Does anyone need help?'

b) Nepotrebuje NIKDO pomoct? neg-needs nobody help

'Nobody needs help?'

c) Von nepotřebuje NIKDO pomoct?

he-expl neg-needs nobody help

'Nobody needs help?'

Second, contrary to NI-phrases, strict NPIs are grammatical in both types of questions, see (22). This contrast parallels Russian $l i$-questions in which negation does not license NI-phrases, but triggers Genitive of Negation (see above). I suggest, therefore, that strict NPIs are licensed before negation moves to the interrogative $\mathrm{C}$, where it loses

7 The expletive status of negation can be supported by the behaviour of PPI. The PPI in the sentence is interpreted (as expected) only with the wide scope with respect to negation, while the PPI in the sentence (ii) with V(Neg)-raising is not. I thank Mojmír Dočekal for this observation.

(i) Někdo nepotkal včera Karla? = 'is there a specific $\mathrm{x}$ who did not meet Karel?' somebody neg-met yesterday Karel

(ii) Nepotkal někdo včera Karla? = 'is there or isn't there an $\mathrm{x}$ who met Karel neg-met somebody yesterday Karel ${ }_{\text {acc }}$ 
its negative force. In contrast, NI-phrases must stay in local relation with Negation throughout the derivation. Consequently, expletive negation cannot license NI-phrases at LF, see (23b).
a) Nepotrebuje ani jeden $z$ vás pomoct? neg-needs no one from you help 'Doesn't anyone from you need help?'

b) before Verb(Neg)-raising: $\quad \checkmark\left[_{\mathrm{TP}}\left[_{\mathrm{NegP}} \mathrm{Neg}\left[{ }_{\mathrm{vP}} \ldots\right.\right.\right.$ ani ... $\left.\left.]\right]\right]$

c) after Verb(Neg)-raising: $\quad \checkmark \mathrm{Neg}+\mathrm{C}\left[_{\mathrm{TP}} \ldots\left[_{\mathrm{NegP}}\left[{ }_{\mathrm{VP}} \ldots\right.\right.\right.$ ani $\left.\left.\left.\ldots\right]\right]\right]$

(23) a) before $\operatorname{Verb}(\mathrm{Neg})$-raising: $\checkmark\left[_{\mathrm{TP}}\left[_{\mathrm{NegP}} \mathrm{Neg}\left[{ }_{\mathrm{vP}} \ldots\right.\right.\right.$ ni-phrase ...] $\left.]\right]$

b) after Verb(Neg)-raising: $\quad * N e g+C\left[_{\mathrm{TP}} \ldots\left[_{\mathrm{NegP}}\left[{ }_{\mathrm{vP}} \ldots\right.\right.\right.$ ni-phrase ... $\left.\left.]\right]\right]$

Finally, recall that negation in declarative questions can also have expletive interpretation. This suggests that the verb movement to $\mathrm{C}$ can be covert; consequently, we obtain type A answers to negative declarative questions:
Doktor neni $\quad v$ ordinaci?
$\rightarrow$ LF: doctor neg-is in office? 'The doctor isn't in his office?'
F: Není doktor $v$ ordinaci? Ne (není). neg-is doctor in office no (neg-is) 'He isn't.'

\subsection{Summary}

Negative questions in Czech can be expressed by using either interrogative or declaratives clauses. These two types of clauses behave differently with respect to several properties (presupposition, adverbs, NPIs, see table 2) that can be explained if the sentential negation in interrogative clauses loses its negative force (thus becomes expletive) by virtue of its movement to the C. Importantly, the distribution of type A and B answers described in section 2 also follows from the distinction between true and expletive negation.

Table 2: Interrogative vs. declarative negative questions

\begin{tabular}{|l|c|c|c|}
\cline { 2 - 4 } \multicolumn{1}{c|}{} & Negative interrogatives & \multicolumn{2}{c|}{ Negative declarative questions } \\
\hline Word order & VSO & \multicolumn{2}{c|}{ SVO } \\
\hline NI-phrases & $*$ & Yes & No \\
\hline Negative presupposition & No & True & Expletive \\
\hline Negation & Expletive & B & A \\
\hline Answers & A & \multicolumn{2}{c|}{} \\
\hline
\end{tabular}




\section{BACK TO ANSWERS}

It is generally assumed (since Laka 1990) that answering particles are generated in the polarity projection $(\Sigma \mathrm{P}, \mathrm{PolP})$ in the $\mathrm{CP}$ domain, because they express positive or negative polarity. The concept of the polarity must be, nevertheless, made clearer in order to account for the mixed behaviour of answering particles in Czech.

Following Farkas (2010), I propose to distinguish between absolute and relative polarity or rather between absolute and relative value of the polarity. In declarative clauses, polarity is a feature that has two absolute values: positive $[+]$ and negative $[-]$. The relation between the two polarity values can be called relative polarity. In the case of question-answer pairs, relative polarity indicates the relation between the polarity of the question $[\mathrm{Q}]$ and the polarity of the answer $[\mathrm{A}]$. There are four possible relations: either [Q] and [A] have the same positive or negative value, or they have different values, one being positive and the other negative. The basic idea is that the particle ano ('yes') expresses the positive value [+], or (by default) the relation between two identical values: $[+,+]$ and $[-,-]=[+]$. The particle $n e($ 'no') expresses the negative value $[-]$, or (by default) the relation between two different values: $[+,-]$ and $[-,+]=[-]$.

\subsection{Expressing Polarity in Answers to Interrogative Clauses}

Positive interrogatives have open polarity ( $x$, cf. Holmberg 2001), because they ask whether $[\mathrm{P}]$ or $[$ not $\mathrm{P}],[\mathrm{P}]$ corresponding to the positive polarity value and $[$ not $\mathrm{P}]$ to the negative polarity value. The particles are minimal answers in that they only indicate the polarity value of the $\mathrm{P}$, the $\mathrm{P}$ itself being presupposed (and elided). The polarity head of PolP receives its value by specifier-head agreement with the particle in its specifier:

Chtěl $l_{x}$ byste šálek čaje? wanted be.cond.2pl cup of-tea 'Would you like a cup of tea?'
a) $\left[_{\mathrm{PolP}} A n o_{[+]}\left[\left[_{\mathrm{Pol}[]}\left[{ }_{\mathrm{XP}} \varnothing\right]\right]\right] \quad(=\right.$ chtěl $)$ yes wanted 'I would like a cup of tea.'
b) $\left[_{\mathrm{PolP}} N e_{[-]}\left[_{\mathrm{Pol},[]}\left[{ }_{\mathrm{XP}} \varnothing\right]\right]\right] \quad$ (= nechtěl $)$ no neg-wanted 'I wouldn't like a cup of tea.'

Assuming that negation becomes expletive by virtue of $\mathrm{Verb}(\mathrm{Neg})$-raising, negative interrogatives also have open polarity and therefore behave like positive interrogatives. Consequently, they are answered by type A answers:
Nechtěl $x_{x} \quad$ byste šálek čaje? neg-wanted be.cond.2pl cup of-tea 'Wouldn't you like a cup of tea?'
a) $\left[_{\mathrm{PolP}^{2}} A n o_{[+]}\left[\left[_{\mathrm{Pol}^{\prime}[]}\left[{ }_{\mathrm{XP}} \varnothing\right]\right]\right](=\right.$ chtěl $)$ yes wanted 'I would like a cup of tea.'
b) $\left[_{\mathrm{PolP}} N e_{[-]}\left[{ }_{\mathrm{Pol}}\left[{ }_{1}\left[{ }_{\mathrm{XP}} \varnothing\right]\right]\right]\right.$ (= nechtěl $)$ no neg-wanted 'I wouldn't like a cup of tea.'


To say that negative interrogatives behave as positive interrogatives with respect to negation does not mean that they are completely equivalent. They cannot, for instance, be used to initiate a line of inquiry or to raise an issue as open or unsettled, as shown in (27). On the contrary, they are willingly used as polite requests and to solicit advice or an opinion, see (28). ${ }^{8}$

a) Máte děti? Pokud ano, chodí / \#nechodí do školy? have.2pl children if yes they-go/ neg-go to school 'Have you got children? If yes, do / \#don't they go to school?'

b) Co myslite, bude/\#nebude François Hollande znovu zvolen prezidentem? what think.2pl will / neg-will François Hollande again elected president 'What do you think, will / \#will not François Holland be re-elected president?' Může být, ale také nemusí. he-can be but also neg-must 'It could go either way.'

a) (v tramvaji) Chcete / Nechcete pustit sednout? (in a tram) want.2pl/neg-want.2pl let sit 'Would(n't) you like to take my seat?'

b) Co myslís,, mám/ nemám se nechat ostřihat? what think.2sg I-have / neg-have refl. let hair-cut 'What do you think, should(n't) I get my hair cut?'

As noted by Brown \& Franks (1995), negative interrogatives must, thus, be endowed with some specific communicative and pragmatic value. Negative interrogatives in Czech are actually considered as more polite or less direct than the positive ones. ${ }^{9} \mathrm{I}$ suggest the following explanation for such a politeness effect. ${ }^{10} \mathrm{~A}$ polar question asks the addressee to choose between two alternatives, positive or negative ( $\mathrm{P}$ or not $\mathrm{P}$ ), but refusing or saying no can be perceived as rude, and, therefore, difficult to express. By using the negative form of the question, the speaker presents the negative alternative as acceptable and consequently allows the addressee to express his refusal more easily. It is precisely because negation has lost its truth-conditional role that it can play such a role at the discourse level (see Groenendijk \& Stokhof 1997).

8 A detailed semantic and pragmatic approach of these questions can be found in Reese (2006) and Krifka (2012).

9 See Leech (2014: 167) for negation as "a strategy to express a degree of polite indirectness".

10 A similar effect can be observed with negative-raising. The sentences Nemyslím, že s tím bude souhlasit ('I don't think he will agree with that') and Myslim, že s tím nebude souhlasit ('I think he will not agree with that') are semantically equal (i.e. the negation is interpreted in the embedded clause), but only the raised negation adds a politeness effect to the sentence interpretation. 


\subsection{Polarity in Answers to Declaratives Clauses}

I have said above that declarative clauses have their polarity feature specified. The value of the polarity feature in negative declarative clauses is negative. Likewise, negative declarative clauses used as questions have a negative polarity value. That is the reason why they convey a negative presupposition (see section 3.1). The answer confirms or disconfirms this negative presupposition. Consequently, the particles only indicate relative polarity, i.e. relation between the polarity of the question and that of the answer. ${ }^{11}$

Oni ten návrh nepřijali ? they the proposal neg-accepted

'They didn't accept the proposal?

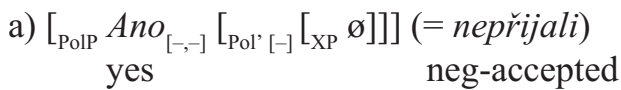
'They didn't.'

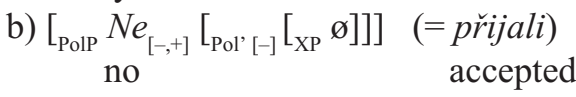
'They did.'

Importantly, this analysis can be extended to positive questions conveying a positive presupposition, as in (30). But there will be no difference at surface between answers expressing absolute polarity and those expressing relative polarity. In both, (25) above and (30) below, the positive answer will be expressed by "ano + positive verb", and the negative answer by "ne + negative verb". The mixed behaviour of the particles can therefore be only observed with negative questions.

Oni ten návrh přijali ${ }_{[+]}$? they the proposal accepted 'They accepted the proposal?'
a) $\left[_{\mathrm{PolP}^{2}} A n o_{[+,+]}\left[\left[_{\mathrm{Pol}{ }^{\prime}[+]}[\mathrm{XP} \varnothing]\right]\right](=\right.$ prijali $)$ yes accepted 'They did.'

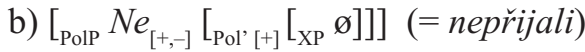 no neg-accepted 'They didn't.'

Particles are, therefore, not ambiguous, but their felicitous use depends on the felicitous interpretation of the question. This can be resolved by using specific prosody schemes to indicate biased or focused interpretation. Finally, the proposed analysis predicts that the mixed behaviour of particles can be observed in languages in which negation raising to a particular $\mathrm{C}$ leads to its expletive interpretation and in which declarative clauses can be used as questions. This prediction seems to come true e.g. for Russian and Spanish (see Gruet-Skrabalova 2014), as shown in (31) and (32) respectively. ${ }^{12}$ This issue is, however, out of the scope of this paper and must be left to future research.

11 Ano in (29) cannot be itself (without ale 'but') interpreted as "they did accept". Ne is theoretically ambiguous, but in practice, the ambiguity will be resolved by the intonation of both question and answer (see section 3.2., ex. (16) and (16'), and section 3.4 ex. (24)).

12 These examples come from my Russian and Spanish informants. 
a) Ne priexali li roditeli domoj? Net, ne priexali. // Da, priexali. neg came part. parents at-home 'Haven't the parent come at home?' no neg came yes came

b) Roditeli ne priexali domoj? DA ne priexali.//NET, priexali. parents neg came home yes neg came no came 'The parents haven't come at home?'

a) ¿No están en casa los padres? neg are at home the parents 'Aren't the parents at home?'

b) ¿Los padres no están en casa? the parents neg are at home 'The parents aren't at home?'
No, no están. // Si, están.

no neg are yes are

'SI, no están. // NO, están.

YES neg are // NO are

\section{CONCLUSION}

In this paper, I have dealt with answers to negative yes-no questions, focusing on data from Czech. I have shown that answering particles can express both positive and negative answers to negative questions, but that their distribution depends on the semantic and syntactic properties of questions. I have argued that negation in questions loses its negative force when it moves to the interrogative head $\mathrm{C}$ and behaves thus as expletive negation. Consequently, I have distinguished between two types of negative questions: (i) negative interrogative clauses that contain an initial negative verb and expletive negation, and that do not convey a negative presupposition, and (ii) negative declarative clauses used as questions, that contain a non-initial negative verb and true negation, and that convey a negative presupposition. Following this syntactic and semantic distinction, I have shown that negative interrogatives receive the same answers as positive interrogatives (yes in case of positive answer and no in case of negative answer), while negative declaratives used as questions are confirmed by yes (corresponding to a negative answer) and denied by no (corresponding to a positive answer). I have explained this distribution by proposing that the particles express absolute polarity in answers to interrogative questions, whose polarity is open and must be fixed by the particle, and relative polarity in answers to declarative questions, whose polarity has been already specified.

\section{References}

ABELS, Klaus (2002) "Expletive (!) Negation.” In: J. Toman (ed.), Proceedings of FASL 10, 1-20.

BEYSSADE, Claire/Jean-Marie MARANDIN (2006). "The Speech Act 97 Assignment Problem Revisited: Disentangling Speaker's Commitment from Speaker's Call on Addressee". In: O. Bomani/ P. Cabredo-Hofherr (eds), Empirical Issues in Syntax and Semantics 6, http://www.cssp.cnrs.fr/eiss6/, 37-68.

BROWN, Sue (1999) The Syntax of Negation in Russian. Stanford: CSLI Publications. 
BROWN, Sue/Steven FRANKS (1995) "Asymmetries in the scope of Russian negation." Journal of Slavic Linguistics 3/2, 239-287.

DOČEKAL, Mojmír (2016) "Constituent negation, subjunctive and alternatives." Talk presented at The Olomouc Linguistics Colloquium (Olinco, June 2016), Palacký University Olomouc.

ESPINAL, Maria T. (1992) "Expletive Negation and Logical Absorption." Linguistic Review 9, 333-358.

FARKAS, Donka (2010) “The grammar of polarity particles in Romanian." In: A. Di Sciullo/ V. Hill (eds), Edges, Heads, and Projection: Interface properties, Amsterdam: John Benjamins, 81-124.

FARKAS, Donka F./Kim B. BRUCE (2010) "On reacting to assertions and polar questions." Journal of Semantics 27, 81-118.

GAJEWSKI, Jon (2011) "Licensing strong NPIs." Natural Language Semantics 19, 109-148.

GROENENDIJK, Jeroen/Martin STOKHOF (1997) "Questions." In: J. van Benthemand/ A. ter Meulen (eds), Handbook of logic and language, Amsterdam: Elsevier, $1055-124$.

GRUET-SKRABALOVA, Hana (2015) "Verbs and particles in answers to polar questions." In: G. Zybatow et al. (eds), Slavic Grammar from a Formal Perspective, Frankfurt am Main: Peter Lang, 197-215.

GRUET-SKRABALOVA, Hana (2014) "Two kinds of minimal answers to yes-no question in Czech and Spanish." XI Congreso Internacional de Lingüística General, 21-23 May 2014, Universidad de Navarra, Pamplona. To appear in A. Gordejuela Senosiáin et al. (eds), Lenguas, lenguaje y lingüística. Contribuciones des de la Lingüística General. Pamplona: Servicio de Publicaciones de la Universidad de Navarra.

GUNLOGSON, Christine (2001) True to form: Rising and Falling Declaratives as Questions in English. PhD diss., Univ. of California at Santa Cruz.

HAMBLIN, Charles L. (1973) "Questions in Montague English." Foundations of Language 10, 41-53.

HOLMBERG, Anders (2001) “The syntax of yes and no in Finnish." Studia linguistica $55,141-174$.

HOLMBERG, Anders (2012) "On the syntax of yes and no in English." Newcastle Working Papers in Linguistics 18, 52-72.

HOLMBERG, Anders (2013) "The syntax of negative questions and their answers." In: N. Gato et al. (eds), Proceedings of GLOW in Asia 9, 1-18.

HUDDLESTON, Rodney (1994) "The contrast between interrogatives and questions." Journal of Linguistics 30/2, 411-439.

KRIFKA, Manfred (2013) "Response particles as propositional anaphors." Proceedings of SALT 23, 1-18.

LAKA, Itziar (1990) On the Syntax of Negation: On the nature of functional categories and projections. $\mathrm{PhD}$ diss. Cambridge, MIT.

LEECH, Geoffrey (2014) The Pragmatics of Politeness. New York: Oxford University Press. 
MARTINS, Ana (1994) "Enclisis, VP-deletion, and the nature of Sigma." PROBUS 6/2-3, 173-206.

POPE, Emily N. (1972) Questions and answers in English. PhD. Diss. MIT.

REESE, Brian J. (2006) "The Meaning and Use of Negative Polar Interrogatives." In:

O. Bonami/ P. Cabredo Hofherr (eds), Empirical Issues in Syntax and Semantics 6, 331-354.

\section{Summary \\ YES OR NO, OR HOW TO ANSWER A NEGATIVE QUESTION}

This paper deals with answers to negative yes-no questions, focusing on data from Czech. It is shown that answering particles can express both positive and negative answers to negative questions, but that their choice is not free. Several pieces of evidence are discussed in order to show that the use of the particles depends on the interpretation of negation in the question: expletive negation or true negation. This semantic distinction is furthermore tightly linked to the syntactic position of the negation, according to which we distinguish between negative interrogative clauses and negative declarative clauses used as questions. An analysis in terms of absolute and relative polarity is proposed to account for the mixed behaviour of answering particles: particles express absolute polarity in answers to interrogative questions, whose polarity is open, and relative polarity in answers to declarative questions, whose polarity has been already specified.

Keywords: yes-no question, answer, answering particles, negation, polarity

\section{Povzetek}

\section{$D A$ ALI $N E$, ALI KAKO ODGOVORITI NA NIKALNO VPRAŠANJE}

Pričujoči članek obravnava odgovore na nikalna $d a$-/ne-vprašanja s posebnim poudarkom na češčini. Obravnava primerov pokaže, da členka ano in ne, ki se uporabljata $\mathrm{v}$ odgovorih na nikalna $d a$-/ne-vprašanja, lahko izražata tako soglašanje kot zavračanje, vendar njuna izbira ni poljubna. Podatki pokažejo, da je raba posameznega členka odvisna od vrste zanikanja v vprašanju: to je lahko pravo/stavčno zanikanje ali pleonastično zanikanje. Različna pomenska interpretacija členka je odvisna tudi od skladenjskega položaja nikalnice. Glede na ta kriterij avtorica loči nikalne vprašalne povedi od nikalnih povednih povedi, ki se uporabljajo kot vprašanja. Različno rabo in interpretacijo členkov avtorica pojasni z vidika absolutne in relativne polarnosti: $\mathrm{v}$ odgovorih na povedi $\mathrm{z}$ vprašalnico, katerih polarnost je odprta, členka izražata absolutno polarnost, medtem ko izražata relativno polarnost $\mathrm{v}$ odgovorih na povedna vprašanja, ki so rabljena vprašalno in katerih polarnost je že predhodno specificirana.

Ključne besede: $d a$-/ne-vprašanja, odgovori, členki, nikalnost, polarnost 